\title{
Technology Acceptance Model for Zimbabwe: The Case of the Retail Industry in Zimbabwe
}

\author{
Cinderella Dube ${ }^{1}$, Victor Gumbo ${ }^{2}$ \\ ${ }^{1}$ Research and Innovation Office, National University of Science and Technology, Bulawayo, Zimbabwe \\ ${ }^{2}$ Department of Mathematics, Faculty of Science, University of Botswana, Gaborone, Botswana \\ Correspondence: Cinderella Dube, Research and Innovation Office, National University of Science and Technology, \\ Bulawayo, Zimbabwe.
}

Received: February 8, 2017

doi:10.11114/aef.v4i3.2208
Accepted: March 9, $2017 \quad$ Available online: March 23, 2017

URL: https://doi.org/10.11114/aef.v4i3.2208

\begin{abstract}
The retail industry in Zimbabwe has embraced the use of a variety of technologies in order to survive in this ever changing technological era. However, little research has been done on the adoption and use of these technologies and no model has been developed to date. The aim of this paper was to develop a model best suited to the Zimbabwean retail industry in order to enhance the successful adoption and use of online transaction platforms. The online transaction platforms used to develop the model were Internet banking, Automated Teller Machines, Mobile banking and Point of Sale. A three-sample dataset comprising of 268 bank and supermarket customers, 56 bank managers and 31 supermarket managers was used. Pearson's correlation coefficient was used to determine the relationship between the given factors influencing adoption and use of online transaction platforms and the constructs perceived ease of use and perceived usefulness. The resultant TAMZIM model borrowed ideas from the Technology Acceptance Models proposed by Fred Davis in the mid-80s.
\end{abstract}

Keywords: technology acceptance model, online transactions, internet banking, automated teller machines, mobile banking, point of sale, Technology Acceptance Model for Zimbabwe (TAMZIM)

\section{Introduction}

Over the past two decades, user acceptance of technology has been an important field of study in technology adoption (Chuttur, 2009). There are many theoretical perspectives that have been developed in order to understand how end users make decisions to use technology applications and to predict the use of a system (Hussain, 2013). The most dominant model which has captured the most attention and has been the most frequently used to predict the adoption of technology is the Technology Acceptance Model (TAM) (Chuttur, 2009, Ma \& Liu, 2004 and Hussain, 2013). TAM has also been applied in the study of user adoption of different technologies and has been found to be a reliable and robust model (Vijayasarathy, 2004). Kloppling and McKinney (2004) and Hussain (2013) also add that currently, the most effective tool to describe technology acceptance is TAM. For this reason, this paper sought to adapt Davis's TAM and develop a model that is best suited for the Zimbabwean retail industry in an attempt to increase its predictive power for the Zimbabwean situation.

Over the past few years, Zimbabwe has experienced considerable economic recovery due to the demonetisation of the Zimbabwean dollar and the adoption of multi currencies in 2009, with the United States dollar being the most widely used currency (Jefferis, Chigumira, \& Chipumho, 2013). Despite these achievements, the economy is still facing some challenges which are largely mirrored by the macro-economic constraints in the country. Some of the challenges include the liquidity crunch, lack of capital inflow, lack of production in the country as well as the high cost of doing business. The liquidity crisis is characterised by shortages of cash, high cost of finance and the fact that money in circulation is too limited to meet the demands of an economy that is struggling to strive (Confederation of Zimbabwean Industries Report, 2014). In order to resolve these problems, the Zimbabwean retail industry has been urged to embrace the use of online technologies which enhance online transactions rather than cash transactions.

Research in TAM has been done extensively in developed countries; however, more work still need to be done in developing countries. Most research on online technology platforms in Zimbabwe has concentrated on the adoption rates whereas a few have gone further to identify factors influencing the adoption of the online transaction platforms. 
Apart from Shambare (2013), who referred his findings to the Technological Readiness Theory, Dube and Gumbo (2017) who referred their findings to the Keynesian Theory of Money and Chitungo \& Munongo (2013) who tested TAM in rural areas, most research in Zimbabwe was not based on any theoretical framework. A gap thus exists where there is lack of a model for the Zimbabwean retail industry. The purpose of this paper is therefore to fill this gap by developing a Technology Acceptance Model for Zimbabwe (TAMZIM).

The proposed model (TAMZIM) borrows from the ideas of Davis' initial model and other models that came after it. This was in essence an extension of the model where constructs, Perceived Usefulness (PU) and Perceived Ease of Use (PEOU) were compared (cross-tabulated) with factors influencing the adoption and use of online transactions using Pearson's correlation coefficient. The model relates these factors as they each directly influenced behavioural intention. Behavioural intention in turn was used as it directly influenced actual use of online transactions. The relationship between demographic factors (age, gender, occupation and educational qualifications), PU and PEOU are also presented. The demographic factors were viewed as moderators of the effect of these factors influencing adoption and use of online transactions as they influence PU and PEOU.

\section{Review of Literature}

\subsection{Technology and Acceptance}

Acceptance in general refers to an agreement to something and it involves both acting and believing in the idea or technology in question. It involves taking up as well as the continued use of a product, service or idea (Myers, 2015). In agreement with Myers, Hall, \& Khan (2002) posit that technology acceptance is therefore the choice to acquire and adopt a new invention or innovation. In this study the new inventions were online transaction platforms, namely, Automated Teller Machines (ATM), Internet banking, Mobile banking and Point of Sale (POS) as they are used in the retail industry.

\subsection{The Retail Industry}

An industry is a group of firms that offer a product or service or class of products or services that are close substitutes for one another. Retailing means all activities involved in selling goods and services directly to the final consumers for their personal use and non-business use (Kotler and Keller, 2006). Therefore, in this paper, the retail industry refers to the banking industry and supermarkets. Banks provide a wide range of financial services to all sectors of the economy and are governed by the Central Bank of a country. The major functions of banks include accepting deposits, money transfers, advancing loans, payment of customers' bills and other utility functions (Goyal and Joshi, 2011). On the other hand, supermarkets are businesses that bring together a wide range of goods including food, beverages, over-the counter medicines, detergents, and electrical and non-electrical home and garden goods to a central place where primarily local residents periodically replenish their stock of household products (Steeneken and Ackley, 2012). Banks and supermarkets were studied together because online transaction platforms from banks are mostly used in conjunction with those in supermarkets as buying groceries is the most likely activity that most people do on a regular basis.

\subsection{Online Transaction Platforms}

In this study, a platform is defined as the basic hardware (computer) and software (operating system) on which online transaction processing can be run. Online Transaction Processing (OLTP) applications are client/server applications that give online users direct access to services and information (Meerapur, 2014). In a banking environment, OLTP entails requesting and receiving money or data from a class of software programs capable of supporting transaction-oriented applications on the Internet (Gilbert and Hewitt, 2013). Therefore, online transactions are password-protected transactions that require a password to authorise the transfer of funds and banking information between the customer and the retailer (Meerapur, 2014).

In this paper, Internet banking is defined as banking done electronically through the bank's website without the intervention of any banking personnel, through one's Personal Computer (PC) or other devices that can access the website through the Internet. In other spheres, Internet banking is synonymous to online banking, e-banking and PC banking (Baten \& Kamil, 2010; Dube, Chitura, \& Runyowa, 2009). Internet banking enables bank customers to transfer funds, pay bills in real time and access general information on bank products and services through the use of the bank's website (Hadadi, Otaif, Faqihi, \& Al- ahmadi, 2006). Automated Teller Machines are defined as electromechanical devices that permit authorised users to use machine-readable plastic cards (which are magnetically encoded), and a personal identification number to withdraw cash from their accounts and/or access other services, such as balance enquiries and transfer of funds in real time (Hossain and Bari, 2006). In this case, the ATM systems are connected to the bank's systems for the retrieval of money and information. Mobile banking is defined as a service that enables customers to access their bank accounts' information, transfer funds or pay bills in real time through their cellphones via a mobile network (Rahmani, Tahvildari, Honarmand, Yousefi, \& Daghighi, 2012). In this case, the bank and the mobile network company get into a partnership and work together to enable Mobile banking transactions. 
A Point of Sale (POS) is the point at which a customer makes a payment to the merchant in exchange for goods or services (Bernardo, 2013). In Zimbabwe, using POS to buy groceries is made convenient by the use of the ZimSwitch platform where customers can access their bank accounts for paying groceries through a single point if their bank has partnered with ZimSwitch (Dube and Gumbo, 2017). ZimSwitch is an online transacting company owned by ZimSwitch Technologies and is the sole national electronic funds switch for Zimbabwe (ZimSwitch Technologies: 2013). Therefore, bank and supermarket customers can use the ATM (through ZimSwith), Internet banking and Mobile banking to buy groceries at the POS system in supermarkets.

\subsection{Factors Influencing the Adoption and Use of Online Transactions}

Factors influencing the successful adoption of online transactions constitute the positive reasons why customers and/or banks would choose to adopt or take up online transactions (Lee, 2009). In studying these factors, the reasons why customers or banks do not adopt or take up online transactions are deduced. In this study, it was the perceived view of the customer as well as the bank and supermarket employees that was sought. The factors that were considered were ease of use, usefulness, enjoyment, availability of Internet, quality of network, accessibility, reliability, affordability, availability of information, advertising, computer literacy, economic growth, security and privacy, attitude towards innovation, marketer's persuasion tools, online service and the amount of income one earns.

Ease of use is the extent to which a product's use is free from effort (Quesenbery, 2001) and usefulness is seen as the probability that using a technology would improve the way a user can complete a given task (Renny, Guritno, \& Siringoringo, 2013). Enjoyment refers to the perceived fun and perceived playfulness of using the technology (Davis, Bagozzi, \& Warshaw, 1989). Availability of Internet enables online transacting to take place through, for example, wireless Internet access and satellite Internet (McDowell, 2014). Quality of network is measured in terms of speed (upload and download speed) and consistency in the rate of upload and download (Visualware, 2007). Accessibility entails proximity, nearness or closeness to a banking/POS service. It can be physical distance, online access, ease of contact, ease of reach and authorisation to retrieve information from various devices (Mutengezanwa, Mauchi, Dube, \& Gombarume, 2014). Reliability is the ability of a technology to perform the assured service accurately and dependably (Roche, 2014).

Affordability is the ability to pay for the product or service (Rojean, 2014). Security entails freedom from danger, doubts, uncertainty and risks such as hacking and viruses. It entails safety and privacy derived from using public networks (Daniel, 1999). Privacy is the degree to which an online product /service is safe and customer information is protected from the possibility of improper use of customers' financial and personal data (Ma, 2012). Availability of information is the amount of facts or knowledge given to improve awareness of a product or service (Nasri, 2011). Advertising is defined as the amount of funds, time and effort put into availing information to customers (Boundless, 2015b).Computer literacy is related to prior experience with computers and entails the consumer's familiarity with technologies in general which facilitates their appreciation of the potential added value which is inherent in a technology (Nasri, 2011). Economic growth is a process whereby an economy's real national income as well as per capita income increases over a long period of time. It implies economic stability (Gono, 2012). Management attitude towards innovation is defined as the banks' or individuals' attitude and reflects either a positive or negative approach towards technological change (Nasri, 2011). Marketer's persuasion tools are related to the amount of funds, time and effort put by banks and supermarkets to persuade customers to use their products/services (Boundless, 2015a). Online service refers to person-to-machine communication which is dependent on the quality of product, fair price, availability, after-sale services, complaints handling process, provision of information and the variety of products available to customers (Ankit, 2011). With regard to the amount of income one earns, it is presumed that the more a person earns, the more they are likely to adopt online technologies since they have more money in their bank accounts for transacting (Al-Ghaith, Sanzogni, \& Sandhur, 2010).

\subsection{Theoretical Frameworks}

The Technology Acceptance Model (TAM) was developed by Fred Davis in 1986 (Figure 1) to predict user acceptance of new technologies (Takele and Sira, 2013). According to Chuttur (2009), Davis considered that the actual use of a system is behaviour and thus the Theory of Reasoned Action (TRA) would be a suitable model to explain and predict that behaviour. He borrowed and used the principles of 'intention to use' to influence behaviour (actual use) in TAM (Klopping and McKinney, 2004). However, Davis did not take subjective norm in Figure 1 into account in influencing intention to use as he was uncertain of its theoretical status (Chuttur, 2009). Although he considered the attitude of a person towards influencing intention, he did not include Fishbein and Ajzen's main beliefs on the consequences of behaviour and what others thought towards a given behaviour. 


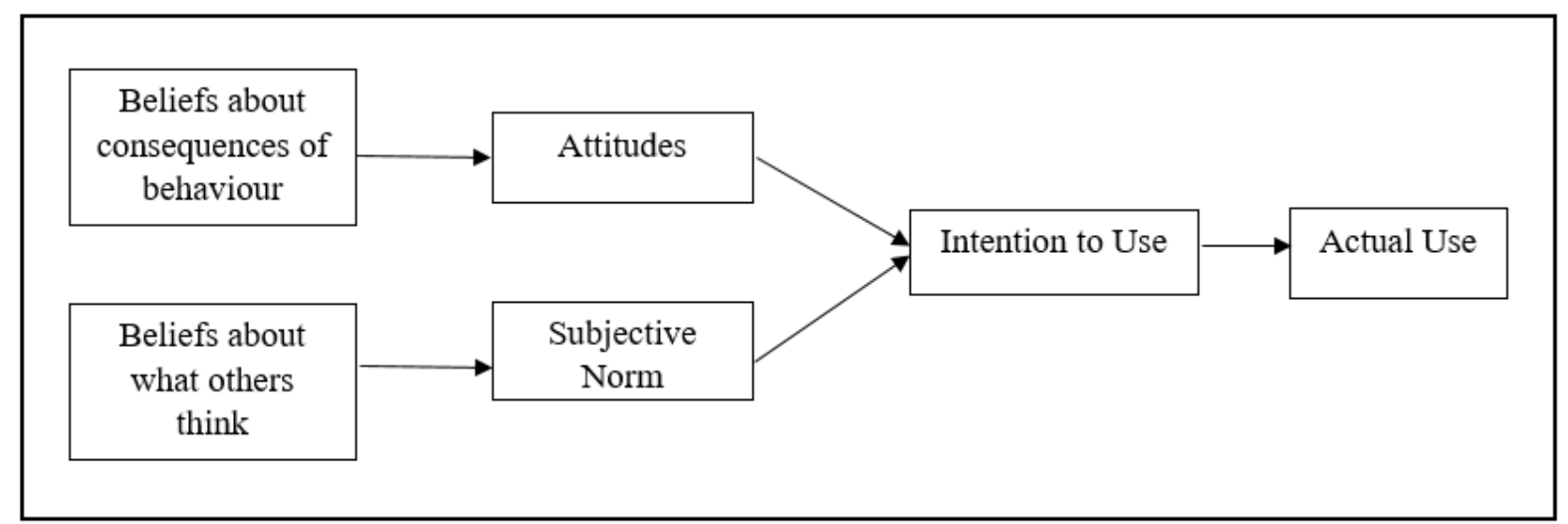

Figure 1. The Theory of Reasoned Action

Source: Tan (2013)

In its place, he identified perceived usefulness and perceived ease of use to be enough to predict the attitude towards behaviour which jointly influenced attitude toward a new technology as shown in Figure 2 (Takele and Sira, 2013). Davis (1986) defined perceived usefulness as the prospective user's subjective probability that using a system will increase their task performance. Perceived ease of use was defined as the degree to which the prospective user expects the system to be free from effort. He proposed that both perceived usefulness and perceived ease of use directly influenced intention to use. Davis (1986) also posited that perceived ease of use influenced perceived usefulness which in turn influenced intention to use and consequently usage behaviour as shown in Figure 2.

Since the theory was borrowed from the field of Psychology, Davis (1986) included the three major learning domains into the theory. Perceived ease of use and perceived usefulness comprised of the cognitive response (mental skills and knowledge domains). The attitude response fell under the affective domain (feelings or emotions) and the behavioral response fell under the psychomotor or physical skills domain as shown in Figure 2.

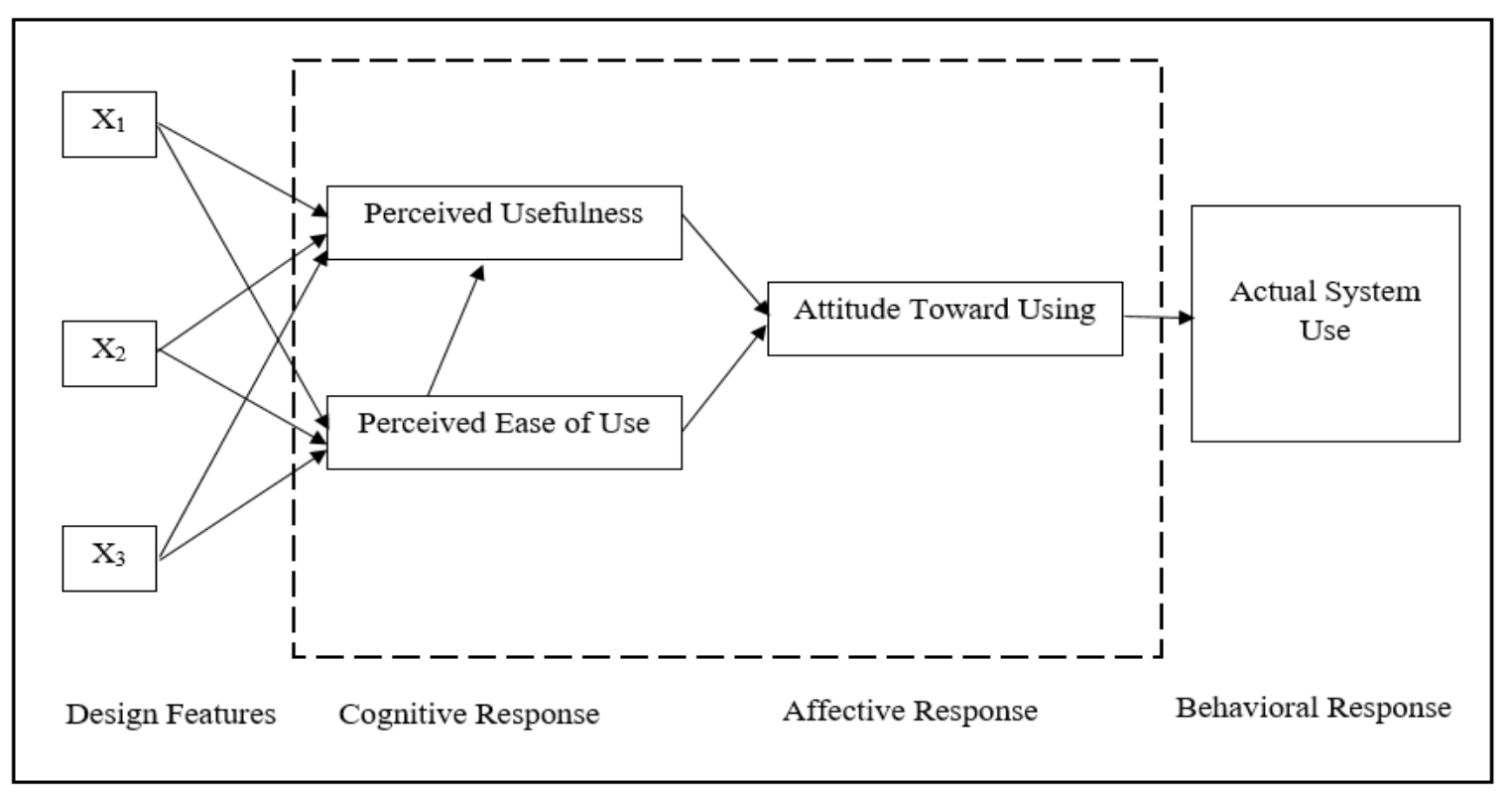

Source: Davis (1986)

The cognitive and affective responses are internal responses and they take place within the individual's mind and are then expressed in the behavioural response. The behavioural response is external and is expressed through acceptance or rejection of the design features $\left(\mathrm{x}_{1}, \mathrm{x}_{2}\right.$ and/or $\left.\mathrm{x}_{3}\right)$. The internal responses are enclosed in the dotted box in Davis' initial model as shown in Figure 2.

In 1989, Davis, Bagozzi and Warshaw extended Davis's initial TAM to include the variable behavioural intention which was influenced by attitude towards use. Behavioural intention then influenced behavioural usage. Davis, Bagozzi, \& Warshaw (1989) posited that perceived usefulness directly influenced behavioural intention. They maintained that 
perceived usefulness was influenced by perceived ease of use which in turn influenced attitude towards use, then behavioural intention and eventually behavioural usage as shown in Figure 3.

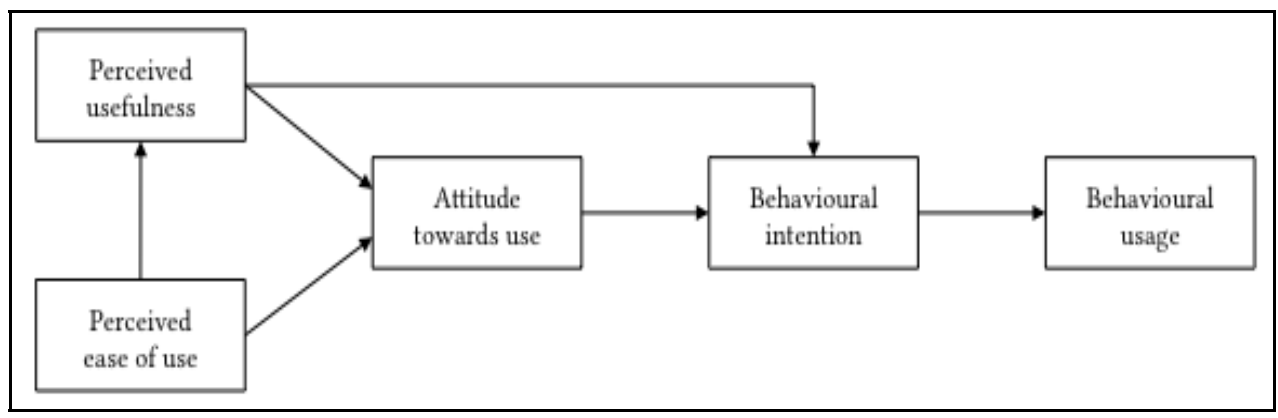

Figure 3. Davis, Bagozzi, \& Warshaw's modified TAM

Source: Davis, Baggozi, \& Warshaw (1989)

The Technology Acceptance Model was again modified by Venkatesh and Davis in 1996. Venkatesh and Davis (1996) removed the attitude variable holding that it eliminated any unexplained direct influences observed from the system's characteristics. However, they added external variables such as factors influencing both perceived usefulness and perceived ease of use. The external variables included system characteristics, user training, user participation in design and the nature of the implementation process although these remained silent on the model as shown in Figure 4.

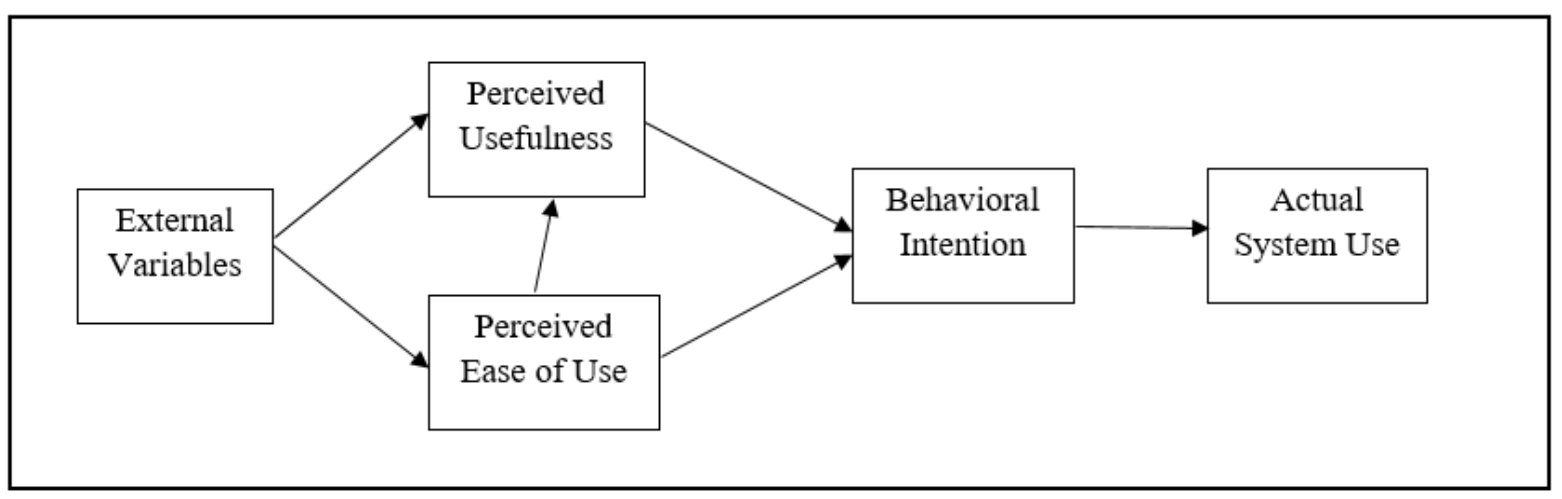

Figure 4. Venkatesh \& Davis's modified TAM

Source: Venkatesh and Davis (1996)

Since 1996, many others have modified TAM in many different ways by developing antecedents to either perceived usefulness or perceived ease of use or both. In 2000, Venkatesh and Davis went on to modify Venkatesh and Davis' TAM and termed it TAM2. TAM2 retained the intention to use and included determinants or factors influencing perceived usefulness. These were subjective norm, image, job relevance, output quality and result demonstrability (Venkatesh and Davis, 2000). In TAM 2 Model, the relationship between subjective norm and perceived usefulness was moderated by experience and that between subjective norm and intention to use was influenced by voluntariness as shown in Figure 5. 


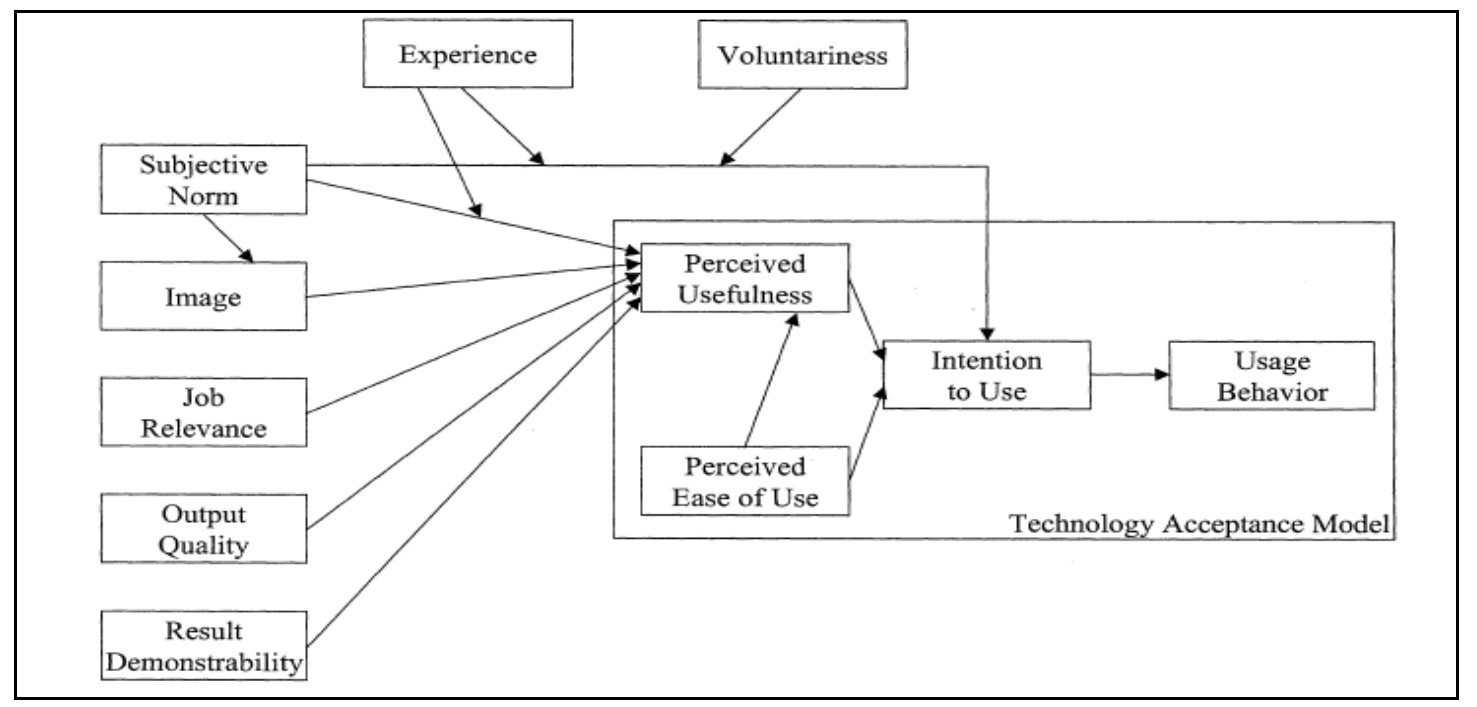

Figure 5. Venkatesh and Davis's modified TAM 2 Model

Source: Venkatesh and Davis (2000)

In 2000, Venkatesh identified antecedents to the perceived use variable and divided the antecedents into two main groups. These were anchors, namely, computer self-efficacy, computer anxiety, computer play-fullness and perceptions of external control and adjustments, namely, perceived enjoyment and objective usability (Venkatesh, 2000). In 2008, Venkatesh and Bala (2008) further developed a model which they termed TAM 3 by combining TAM 2 and Venkatesh's 2000 model. TAM3 combined the determinants of ease of use and the determinants of perceived use (Venkatesh and Bala, 2008).

In 2003, the Unified Theory of Acceptance and Use of Technology (UTAUT) was developed by Venkatesh, Morris, Davis, and Davis in 2003. UTAUT was a combination and fusion of prior technology acceptance research and it had four key constructs that influence behavioural intention to technology use (Venkatesh, Morris, F. Davis, \& G. Davis, 2003). These were performance expectancy, effort expectancy, social influence, and facilitating conditions. Apart from experience and voluntariness being the moderators, UTAUT added two demographic factors, namely age and gender (Venkatesh et al., 2003).

The TAMZIM developed in this paper took the factors influencing adoption of online transactions as antecedents and determinants of PU and PEOU. The TAMZIM also tested age, gender, educational qualifications and occupation as moderators of the relationship between the factors influencing adoption and use and also PU or PEOU.

\section{Method}

The study population comprised of 16 banks located in Harare and the three largest supermarkets in Zimbabwe (located in Harare) that agreed to participate in the study. Harare (the Capital City) was chosen because most head offices of these banks and supermarkets were located there and therefore the views of the participants were presumed to encompass the views of their respective banks and supermarkets countrywide. Non-probability sampling techniques were used to select the samples. Convenience sampling was used to select the sample for bank and supermarket customers and purposive or judgemental sampling was used for selecting the samples for bank and supermarket managers.

Questionnaires were used to collect data for all three samples because questionnaires enable a lot of data to be collected in a short space of time and they were best suited for the constantly busy banking/supermarket environments (Bailey, 1987). The questions asked were closed-ended and comprised of nominal and likert scales (see Appendices A to C). Nominal scales were used to measure background data since they can measure frequencies. The 3-point likert scale was used to measure the degree of agreement and disagreement of how the given factors influenced the adoption and use of online transaction platforms in banks and supermarkets (Bailey, 1987). Three point likert scales were used because in a pilot study conducted in a small town in Zimbabwe (Gwanda), a 5-point likert scale was used and the responses had a lot of non-responses (blank spaces) which could compromise the results and hence the decision to opt for the 3-point likert scale. The decision is supported by Dolnicar, Grün, Leisch, \& Rossiter (2011) who concur that 3-point likert scales are easier to complete than the 5-point or 7-point likert scales which consequently take longer to fill. They also add that 3-point likert scales take the guesswork out of research and suffer from less response style bias resulting in more valid measures being obtained without the loss of predictive validity. 
The collected data was analyzed through the Statistical Package for the Social Sciences (SPSS) computer programme (Version 20) software database for quantitative analysis. Pearson's Product Moment coefficient was used to indicate whether the relationship between variables was a positive relationship (which could be strong, moderate or weak), a negative relationship or no relationship existed at all. The Pearson's product-moment correlation coefficient (Pearson's correlation or $r$ for short) is a measure of the strength and direction of association or relationship that exists between two variables expressed as a single value ranging between -1 and +1 (Sura,2011). As in this case, Pearson correlation just indicates a relationship that was not necessarily an indication of causality.

The larger the value of the coefficient, the stronger the linear relationship between the variables where the absolute value of one $(+1)$ indicates a perfect linear relationship, -1 indicates a perfect positive relationship and value of zero $(0)$ indicates the absence of a linear relationship (Bailey, 1987). Although Gunesh (2005) and Taylor (1990) both agree that there are no set values that demarcate, for example, between weak and moderate and between moderate from strong correlation, they also agree that there are rough guidelines where values between 0.01 and 0.35 are generally considered to represent low or weak correlations, 0.36 to 0.67 represent modest or moderate correlations, 0.68 to 1.0 represent strong or high correlations and 0.90 representing very high correlations. On the other hand, StatPremier (2006) gives a more simplified guideline where a value of less than 0.3 is said to be weak, between 0.3 and 0.7 is considered to be moderate and a value of above 0.7 is considered to be a strong relationship. However, Explorable (2009) and Laerd Statistics (2013) regard a value of 0.5 and above as strong, 0.3 to 0.5 as moderate and 0.1 to 0.3 as weak. Although, it is generally agreed that a value of 0.4 is the most commonly accepted minimum that tends to be acknowledged as a significant relationship, it can be noted that with larger samples, a low strength of correlation, for example, $r=0.3$, can be highly statistically significant (Learntech, 2015). Therefore, in this study, classifications according to Explorable (2009) and Laerd Statistics (2013) were used as a guideline. That is, values of 0.1 to 0.2 were considered to be weak, those from 0.3 to 0.4 were considered to be moderate and those from 0.5 and upwards were considered to be strong.

Factor analysis of the factors influencing adoption and use of online transactions for the three samples were computed using Cronbach's alpha reliability coefficient. Cronbach's alpha reliability coefficient provides a measure of the internal consistency of a set of variables. Internal consistency describes the extent to which all the items in a set measure the same concept or construct (Tavakol and Dennick, 2011). George and Mallery (2003) provide the following rule of thumb for interpreting Cronbach's alpha, _> .9 - Excellent, ${ }_{-}>.8$ - Good, _> $.7-$ Acceptable, $_{-}>.6$ - Questionable, ${ }_{-}>.5$ - Poor and _ $<.5$ - Unacceptable. Therefore, in this paper, a Cronbach's alpha reliability coefficient of .6 and above was considered to be acceptable. The first 5 variables listed in question 5 of Appendix A were used to compute factor analysis for customers. The first 7 variables listed in question 2 of Appendices B and C respectively were used to compute factor analysis for bank and supermarket managers. Fewer variables were used for customers than for bank and supermarket managers because the total variables for customers (11 variables) were less than those for both bank and supermarket managers' questionnaires (14 variables each). The factor, 'availability of information' was used for customers as the researchers thought that it was more appropriate for them whilst 'advertising' was thought to be more appropriate to bank and supermarket employees. Additional factors for banks and supermarkets were online service, management attitude and income. These were also thought to be more appropriate to banks and supermarkets than to customers and hence the difference in the number of factors between the samples.

The SCAMPER (which is an acronym for Substitute, Combine, Adapt, Modify, Put to other uses, Eliminate and Reverse) method of theory formation was used to develop the model (Cheng, 2001). SCAMPER is based on the notion that everything new is a modification of something that already exists (Jennings, 2013).

\section{Results}

Questionnaires were distributed to bank and supermarket customers, bank managers and supermarket managers giving a combined return rate of $67.6 \%$ as shown in Table 1.

Table 1. Response Rates for the different Questionnaire categories

\begin{tabular}{lcccc}
\hline Questionnaire Category & $\begin{array}{c}\text { Gross } \\
\text { Sample }\end{array}$ & $\begin{array}{c}\text { Net } \\
\text { Return }\end{array}$ & $\begin{array}{c}\text { Retur } \\
\text { n Rate }\end{array}$ & $\begin{array}{c}\text { Overall } \\
\text { Response Rate }\end{array}$ \\
\hline Customer Questionnaire & 400 & 268 & $67 \%$ & \\
Banks Questionnaire & 80 & 56 & $70 \%$ & $67.6 \%$ \\
Supermarket Questionnaire & 45 & 31 & $68.9 \%$ & \\
\hline
\end{tabular}

Background information was gathered and it showed that with respect to customers, there were more males than females and that the majority of the customers were between ages $31-40$, had a $1^{\text {st }}$ degree educational qualification and were also employed in the public sector as shown in Table 2. Table 2 also shows that the majority of bank employees were branch managers and the majority of supermarket employees were till operation managers. 
Table 2. Background Information

\begin{tabular}{|c|c|c|}
\hline \multicolumn{3}{|l|}{ Customers } \\
\hline Variable & Category & Percentage \\
\hline \multirow[t]{3}{*}{ Gender } & Male & 57 \\
\hline & Female & 43 \\
\hline & Total & 100 \\
\hline \multirow[t]{6}{*}{ Age } & 30 and below & 35 \\
\hline & $31-40$ & 56 \\
\hline & $41-50$ & 8 \\
\hline & $51-60$ & 1 \\
\hline & 61 and above & - \\
\hline & Total & 100 \\
\hline \multirow{7}{*}{$\begin{array}{l}\text { Educational } \\
\text { Qualifications }\end{array}$} & 'O' Level & 4 \\
\hline & 'A' Level & 10 \\
\hline & Diploma & 21 \\
\hline & 1st Degree & 32 \\
\hline & Masters degree & 29 \\
\hline & $\mathrm{PhD}$ & 4 \\
\hline & Total & 100 \\
\hline \multirow[t]{7}{*}{ Occupation } & Self Employed & 9 \\
\hline & Private Sector & 28 \\
\hline & Public Sector & 50 \\
\hline & Student & 11 \\
\hline & Unemployed & 1 \\
\hline & Retired & 1 \\
\hline & Total & 100 \\
\hline \multicolumn{3}{|l|}{ Bank Employees } \\
\hline \multirow[t]{4}{*}{ Position in Bank } & Branch Managers & 46 \\
\hline & Bank Operations Managers & 36 \\
\hline & ICT Managers & 18 \\
\hline & Total & 100 \\
\hline \multicolumn{3}{|l|}{ Supermarket Employees } \\
\hline \multirow[t]{7}{*}{ Position in Supermarket } & Branch Managers & 10 \\
\hline & Assistant Managers & 13 \\
\hline & Branch Accounting Managers & 16 \\
\hline & Till Operation Managers & 26 \\
\hline & ICT Managers & 16 \\
\hline & Others & 19 \\
\hline & Total & 100 \\
\hline
\end{tabular}

Bank and supermarket customers were asked to indicate the extent to which they thought the given factors influenced adoption and use of the given online transaction platforms in banks and supermarkets on a 3-point likert scale and the results are shown in Figure 6. 


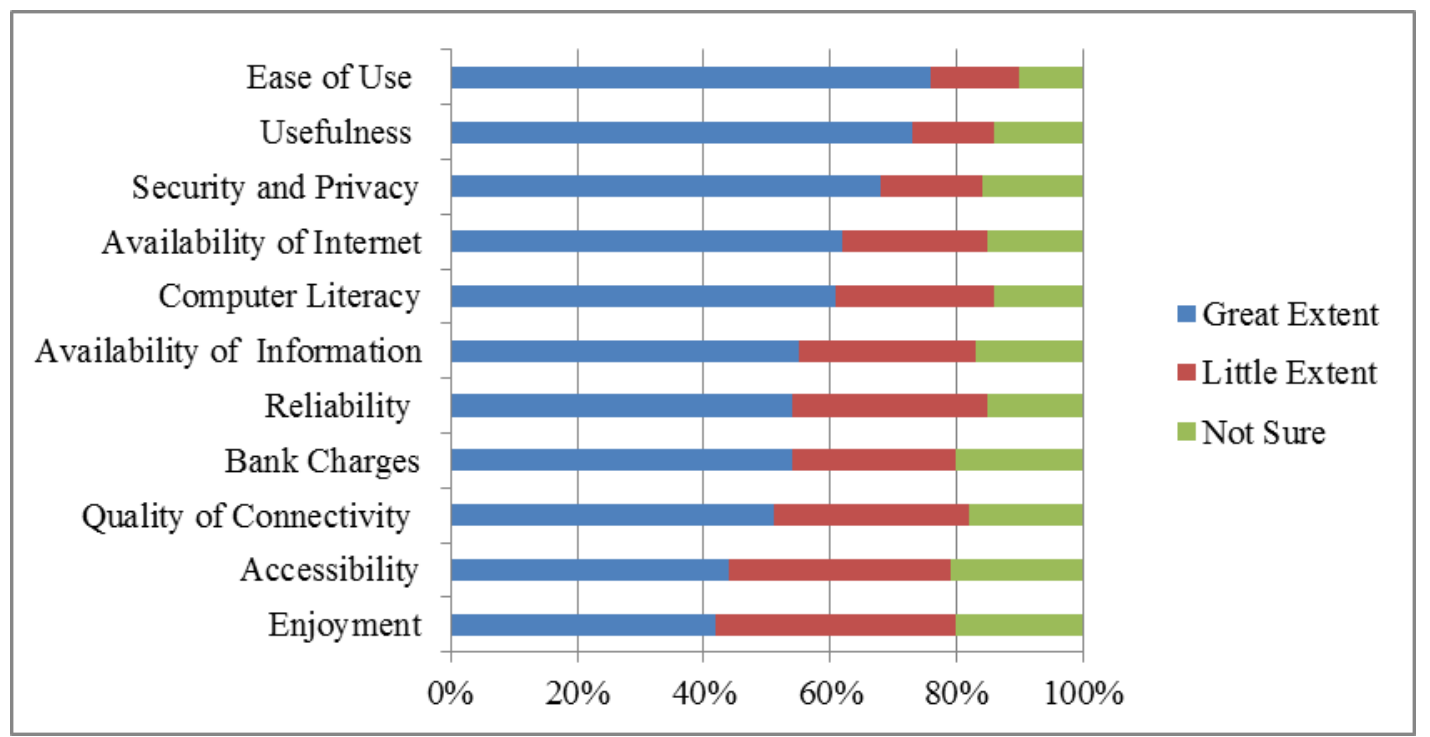

Figure 6. Factors Influencing Customers' Adoption and Use of Online Transaction Platforms

After computing the average percentages of respondents who indicated that the given factors influenced adoption and use to a great extent and to a little extent (Figure 6), the results were ranked and the most influencing factor of adoption and use of online transactions was indicated as ease of use (45\%) as shown in Table 3. This was followed by usefulness $(43 \%)$, computer literacy $(43 \%)$, reliability $(42.5 \%)$, availability of Internet $(42.5 \%)$, security and privacy $(42 \%)$, availability of information $(41.5 \%)$ and quality of connectivity (41\%). The least influencing factors were bank charges (40\%), enjoyment (40\%) and accessibility (39.5\%).

Table 3.Ranked Factors Influencing Customer's Adoption and Use of Online Transaction Platforms

\begin{tabular}{rlrl}
\hline Rank & $\begin{array}{l}\text { Factors influencing Adoption and } \\
\text { Use }\end{array}$ & Rank & Factors influencing Adoption and Use \\
\hline 1. & Ease of use (45\%) & 7. & Availability of information $(41.5 \%)$ \\
2. & Usefulness $(43 \%)$ & 8. & Quality of connectivity (41\%) \\
2. & Computer Literacy (43\%) & 9. & Bank charges (40\%) \\
4. & Reliability (42.5\%) & 9. & Enjoyment (40\%) \\
4. & Availability of Internet (42.5\%) & 11. & Accessibility (39.5\%) \\
6. & Security and Privacy (42\%) & & \\
\hline
\end{tabular}

A Cronbach's Alpha reliability coefficient test was undertaken on 5 variables influencing adoption and use of online transaction platforms (ease of use, usefulness, enjoyment, quality of connectivity and accessibility) using responses from question 5 in Appendix A. The results showed that the Cronbach's Alpha value was 0.710, indicating that the factors had a relatively high internal consistency.

Bank managers were asked to indicate the extent to which they thought the given factors influenced adoption and use of the given online transaction platforms in banks and supermarkets on a 3-point likert scale and the results are shown in Figure 7. 


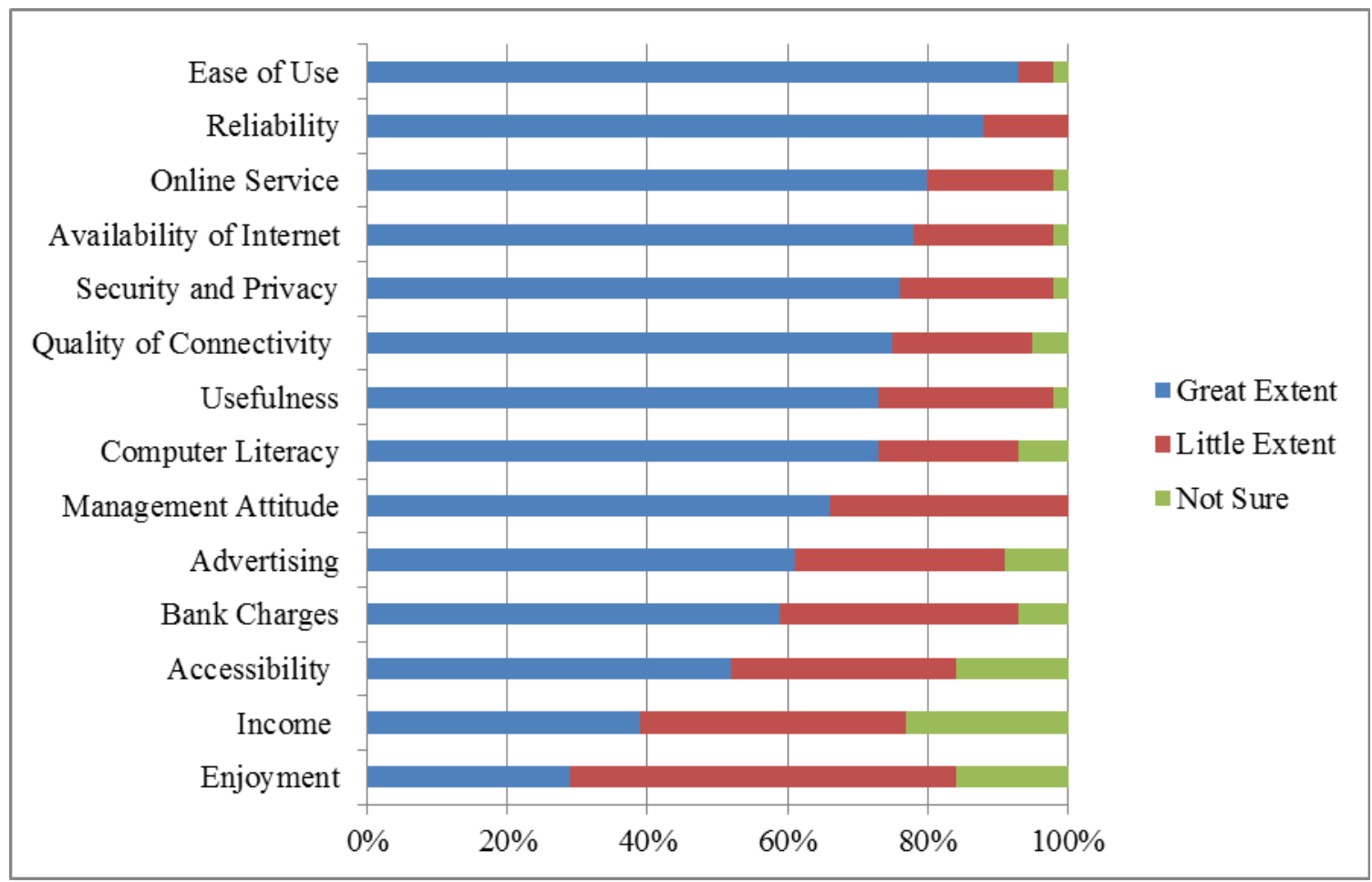

Figure 7. Factors influencing the Adoption and Use of Online Transactions Platforms in Banks

After computing the average percentages of respondents who indicated that the given the factors influenced adoption and use to a great extent and to a little extent (Figure 7), the results were ranked and indicated that the most influencing factors were reliability (50\%) and management attitude (50\%) as shown in Table 4 . These were followed by usefulness (49\%), ease of use (49\%), availability of Internet (49\%), security and privacy (49\%), online service (49\%), quality of connectivity (47.5\%), bank charges $(46.5 \%)$, advertising $(46.5 \%)$ and computer literacy $(46.5 \%)$. The least influencing factors were identified as enjoyment (42\%), accessibility (42\%) and income (38.5\%).

Table 4. Ranked Factors Influencing Adoption and Use of Online Transaction Platforms in Banks

\begin{tabular}{clcl}
\hline Rank & Factor influencing Adoption and Use & Rank & $\begin{array}{l}\text { Factor influencing Adoption and } \\
\text { Use }\end{array}$ \\
\hline 1 & Reliability (50\%) & 8 & Connectivity Quality (47.5\%) \\
1 & Management Attitude (50\% & 9 & Bank Charges (46.5\%) \\
3 & Usefulness (49\%) & 9 & Advertising (46.5\%) \\
3 & Ease of Use (49\%) & 9 & Computer Literacy (46.5\%) \\
3 & Availability of Internet (49\%) & 12 & Enjoyment (42\%) \\
3 & Security and Privacy (49\%) & 12 & Accessibility (42\%) \\
3 & Online Service (49\%) & 14 & Income (38.5\%)
\end{tabular}

A Cronbach's Alpha reliability coefficient test was undertaken on 7 factors influencing adoption and use of online transaction platforms (ease of use, online service, quality of connectivity, bank charges, usefulness, enjoyment and accessibility) using responses from question 2 in Appendix B. The results showed that the Cronbach's Alpha value was 0.756 , indicating that the factors had a relatively high internal consistency.

Supermarket managers were asked to indicate the extent to which they thought that the given factors influenced adoption and use of the given online transaction platforms in banks and supermarkets on a 3-point likert scale and the results are shown in Figure 8. 


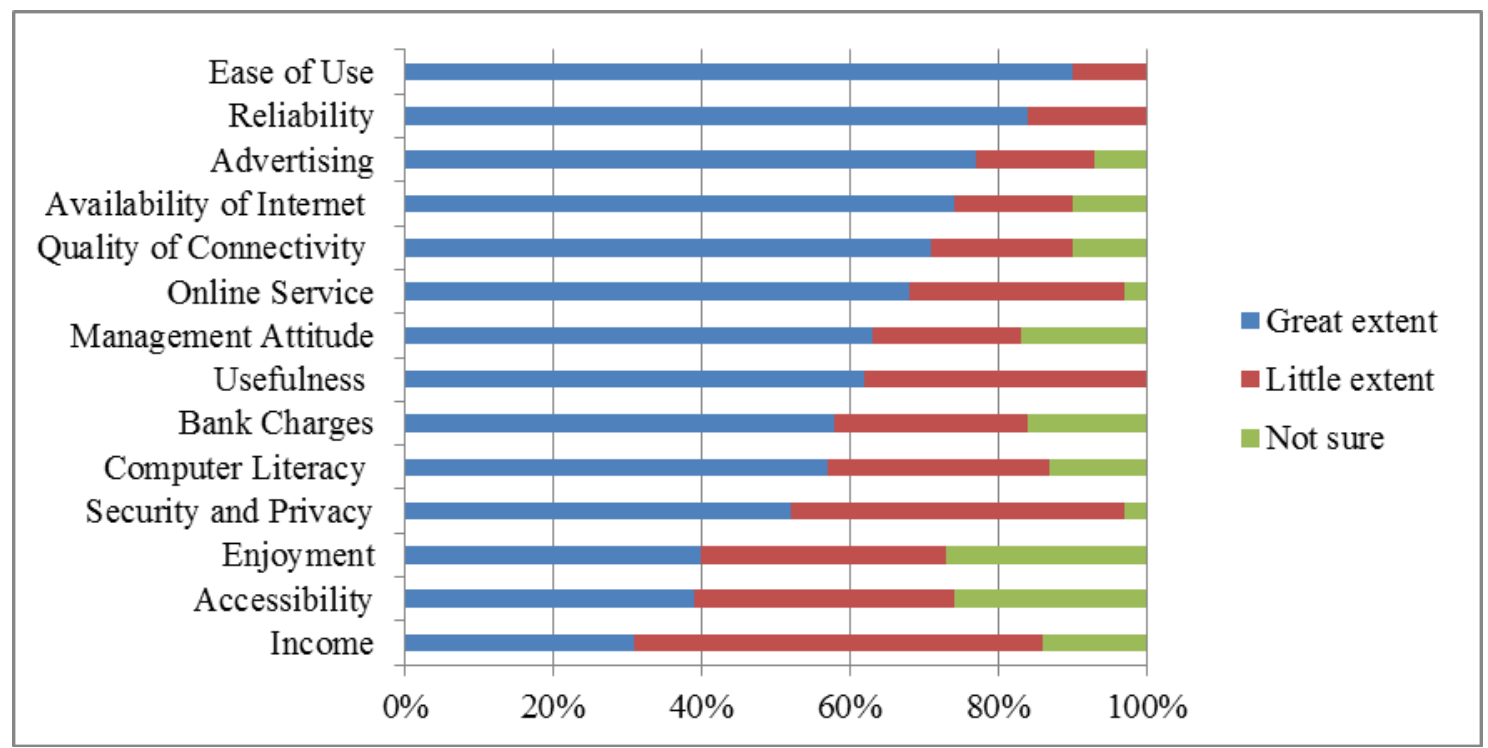

Figure 8. Factors influencing Adoption and Use of Online Transaction platforms in Supermarkets

After computing the averages of percentages of respondents who indicated that the given factors influenced adoption and use to a great extent and to a little extent (Figure 8), the results were ranked and indicated that the most influencing factors were ease of use $(50 \%)$, usefulness $(50 \%)$ and reliability $(50 \%)$ as shown in Table 5 . These were followed by security and privacy $(48.5 \%)$, online service $(48.5 \%)$, advertising $(46.5 \%)$, availability of Internet (45\%), quality of connectivity (45\%), computer literacy $(43.5 \%)$, income (43\%) and bank charges $(42 \%)$. The least influencing factors were management attitude (41.5\%), accessibility (37\%) and enjoyment (36.5\%).

Table 5. Ranked Factors Influencing Adoption and Use of Online Transaction Platforms in Supermarkets

\begin{tabular}{clcl}
\hline Rank & Factor influencing Adoption and Use & Rank & Factor influencing Adoption and Use \\
\hline 1 & Ease of Use (50\%) & 8 & Connectivity Quality (45\%) \\
1 & Usefulness (50\%) & 9 & Computer Literacy (43.5\%) \\
1 & Reliability (50\%) & 10 & Income (43\%) \\
4 & Security and Privacy (48.5\%) & 11 & Bank Charges (42\%) \\
4 & Online Service (48.5\%) & 12 & Management Attitude (41.5\%) \\
6 & Advertising (46.5\%) & 13 & Accessibility (37\%) \\
7 & Availability of Internet (46\%) & 14 & Enjoyment (36.5\%)
\end{tabular}

A Cronbach's Alpha reliability coefficient test was undertaken on 7 factors influencing adoption and use of online transaction platforms (ease of use, usefulness, connectivity quality, bank charges, enjoyment, accessibility and online service) using responses from question 2 in Appendix C. The results showed that the Cronbach's Alpha value was 0.708, indicating that the factors had a relatively high internal consistency.

Pearson's correlation coefficients ( $\mathrm{r}$ ) between the given factors influencing adoption and use of online transactions and $\mathrm{PU}$ and PEOU were computed (using responses from question 5 in Appendix A and also questions 2 in Appendices A and B) and the results are shown in Table 6 . Variables with positive values that could be rounded off to +0.4 or more were listed in Table 6. The correlations were significant at the 0.05 level (2-tailed). Pearson's correlation coefficient (r) between the given factors in question 5 in Appendix A and also question 2 in Appendices B and $\mathrm{C}$ and demographic factors (age, gender, educational qualification and occupation in questions 1 to 4 of Appendix A) were computed and those with a positive relationship were listed in Table 6. The relationships between the given factors influencing adoption and use of online transaction platforms, educational qualifications and occupation were included in Table 6 because the resultant Pearson's correlation coefficient showed either a negative relationship or no relationship at all for all samples. 
Table 6. Correlation between Factors influencing Adoption and Use of Online Transaction Platforms and Perceived Usefulness, Perceived Ease of Use and Demographic Factors

\begin{tabular}{|c|c|c|c|c|}
\hline Variable & Variable & \multicolumn{2}{|c|}{ Pearson's correlation coefficient $(\mathbf{r})$} & \multirow{2}{*}{$\begin{array}{l}\text { Interpretation } \\
\text { asaction Platforms }\end{array}$} \\
\hline \multicolumn{4}{|c|}{ Relationship between Perceived Usefulness and factors influencing Adoption and Use of Online Transaction Platforms } & \\
\hline Perceived & Ease of use & 0.54 & 0.5 & Strong \\
\hline \multirow[t]{10}{*}{ Usefulness } & Enjoyment & 0.53 & 0.5 & Strong \\
\hline & Reliability & 0.40 & 0.4 & Moderate \\
\hline & Bank charges & 0.37 & 0.4 & Moderate \\
\hline & Availability of information & 0.53 & 0.5 & Strong \\
\hline & Computer literacy & 0.44 & 0.4 & Moderate \\
\hline & Availability of Internet & 0.41 & 0.4 & Moderate \\
\hline & Online Service & 0.36 & 0.4 & Moderate \\
\hline & Accessibility & 0.37 & 0.4 & Moderate \\
\hline & Security and privacy & 0.37 & 0.4 & Moderate \\
\hline & Income & 0.45 & 0.5 & Strong \\
\hline
\end{tabular}

Relationship between Perceived Ease of Use and factors influencing Adoption and Use of Online Transaction Platforms

$\begin{array}{lllll}\text { Perceived } & \text { Reliability } & 0.46 & 0.5 & \text { Strong } \\ \text { Ease of Use } & \text { Bank charges } & 0.38 & 0.4 & \text { Moderate } \\ & \text { Security and privacy } & 0.44 & 0.4 & \text { Moderate } \\ & \text { Availability of information } & 0.41 & 0.4 & \text { Moderate } \\ & \text { Computer literacy } & 0.51 & 0.5 & \text { Strong } \\ & \text { Availability of Internet } & 0.39 & 0.4 & \text { Moderate } \\ & \text { Management attitude } & 0.43 & 0.4 & \text { Moderate }\end{array}$

Relationship between Demographics and factors influencing Adoption and Use of Online Transaction Platforms

$\begin{array}{lllll}\text { Gender } & \text { Reliability } & 0.13 & 0.1 & \text { Weak } \\ & \text { Computer literacy } & 0.21 & 0.2 & \text { Weak } \\ & \text { Availability of information } & 0.19 & 0.2 & \text { Weak } \\ \text { Age } & \text { Enjoyment } & 0.10 & 0.1 & \text { Weak } \\ & \text { Bank charges } & 0.11 & 0.1 & \text { Weak }\end{array}$

Using Table 6, TAMZIM was constructed as shown in Figure 9. The thick arrows (black) have a positive relationship of +.5 representing a positive strong relationship. The arrows with medium thickness (blue) have a +.4 representing a positive medium relationship and the thinnest arrows (red) have +.1 and +.2 representing a positive weak relationship. The relationship between perceived ease of use and perceived usefulness was also computed and was found to be positive and strong with a value of +.5 and is therefore represented by a thick (black) line on Figure 9. The model retained Davis' internal processes where perceived usefulness and perceived ease of use directly influenced behavioural intention which in turn influenced the use of online transaction platform as illustrated in Figure 9. 


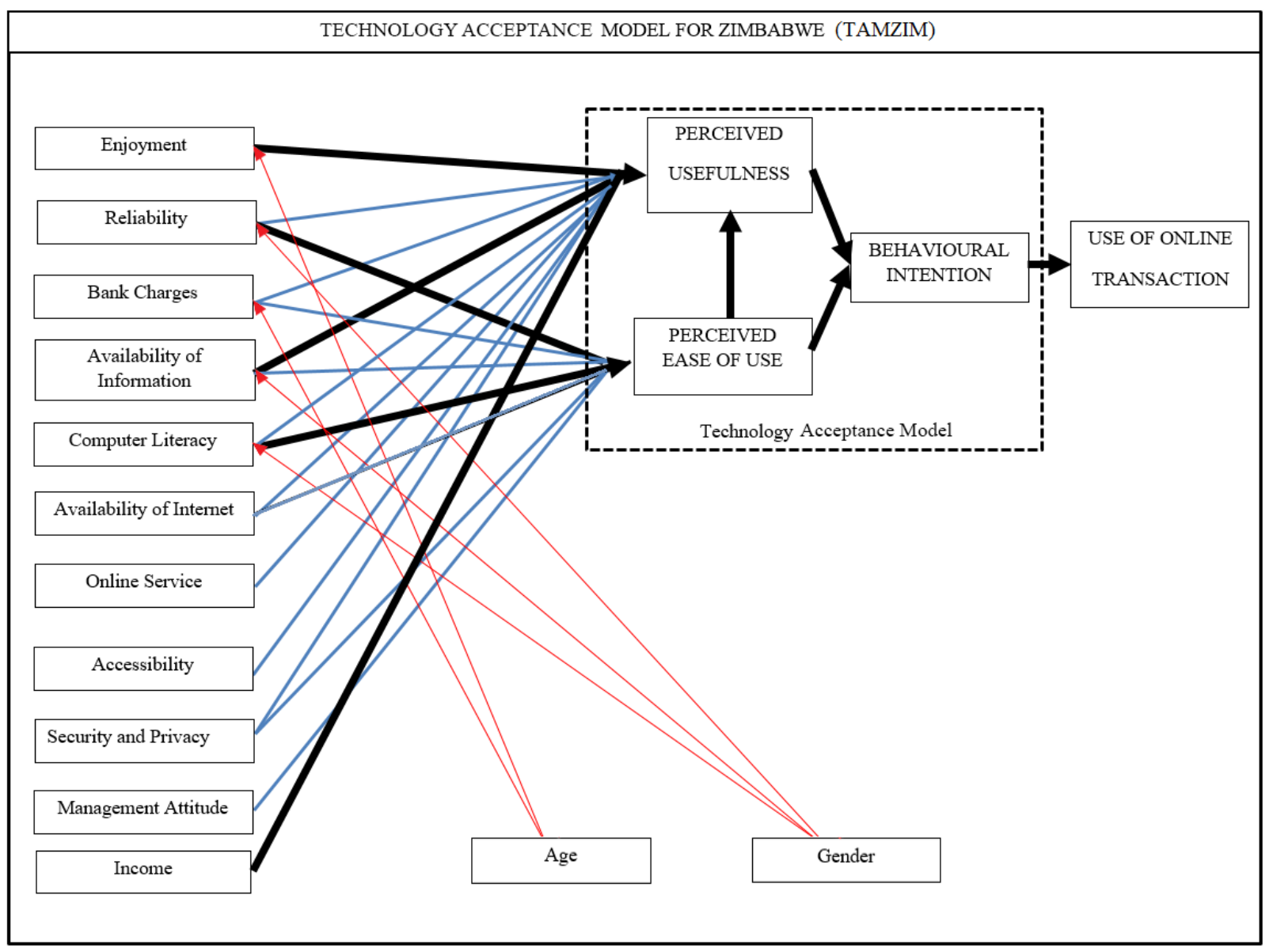

Figure 9. The Technology Acceptance Model for Zimbabwe (TAMZIM)

\section{Discussion and Conclusion}

From the customers' point of view, the greatest influencing factor for the adoption and use of online transaction platforms was ease of use (Figure 6 and Table 3) and this showed that customers were mostly interested in how to use online transactions as supported by Davis (1986) in TAM (Figure 2) who identified ease of use as an important factor influencing behavioural intention. This is also supported by Quesenbery (2001) who posits that ease of use is important as the technology must be free from effort in its use for customers to adopt it. Perceived usefulness was identified as the second most important factor because technology makes transacting convenient as time is saved and customers' lives are made easier as supported by Renny, Guritno, \& Siringoringo (2013). Reliability was also another important factor because customers need to be sure that the online transaction platforms provide the required services accurately and dependably as supported by Roche (2014).

From the bank managers' perspective, the greatest factors influencing the successful adoption and use of online transactions in the retail industry were reliability and management attitude (Figure 7 and Table 4). The authors presumed that managers ought to make sure that their products are working all the time for customers to use them as supported by Roche (2014).Management attitude (towards innovation) was identified as an important factor for bank managers as it determines how the bank responds to innovation which further determines whether it is likely to support the adoption of online transaction platforms as supported by Steward (1996) and Nasri (2008). For banks, the other important factors were usefulness, ease of use, availability of Internet, security and privacy and online customer service. Bank managers are thus aware that customers cannot use online transactions without the availability of Internet which also needs to be reliable. Security and privacy bring the need for online transactions to be safe to use so that customer information is protected with no risk of losing money through hacking and the possibility of improper use of their financial and personal data as supported by Ma (2012) and Daniel (1999).

From the supermarket managers' point of view, ease of use, usefulness and reliability (Figure 8 and Table 5) were the greatest influencing factors for successful adoption and use of online transactions. This entails that, the POS platform must be easy to use for both the customer and the service provider as the human merchant and the POS machine jointly serve the customer who comes face-to-face with the human merchant for the transaction to take place. Therefore the 
technology needs to be reliable in service delivery and the human merchant needs to be knowledgeable in their service provision as supported by Padoa- Schioppa (2003). With ease of use and reliability, POS becomes useful due to the convenience it brings.

The Pearson's correlation coefficients (r) between factors influencing adoption and use of online transaction platforms and PU and PEOU in Table 6 and Figure 9 indicate that the relationship between perceived ease of use and perceived usefulness was confirmed as it resulted in a positive value of 0.5 which was interpreted to be strong. There was a strong relationship between perceived usefulness and enjoyment, availability of information and income. There was also a strong relationship between perceived ease of use and reliability and computer literacy. There was a moderate relationship between perceived usefulness and reliability, bank charges, computer literacy, availability of Internet, online service, accessibility and security and privacy. There was also a moderate relationship between perceived ease of use and bank charges, availability of information, availability of Internet, security and privacy and management attitude to online transactions.

Age moderated the relationship between bank charges and perceived usefulness, in that the older the age, the more the people are likely to adopt online transactions. This situation is unique to Zimbabwe because the youth are unemployed therefore have little or no money in the bank and hence do not feel the effects of bank charges. On the other hand, age moderated the relationship between enjoyment and perceived usefulness in that younger generations were more likely to use online transactions (if they were employed) than older generations as they are more techno savvy and thus enjoy using technology. Gender moderated the relationship between computer literacy and perceived ease of use and perceived usefulness in that men are more likely to use online transactions because of their usefulness than women. The relationship between reliability and perceived ease of use and perceived usefulness was moderated by gender in that men found online transactions easier to use and more useful than women did. Gender also moderated the relationship between availability of information and perceived ease of use and perceived usefulness in that men most probably had more information on online transactions than women thus they used them more than women. The results entail that banks and supermarkets should put more effort in the strong relationships without ignoring the moderate and weak relationships.

From Tables 3, 4 and 5, we conclude that the most important factors influencing the adoption and use of online transaction platforms in the retail industry in Zimbabwe were ease of use, usefulness and reliability. Ease of use and usefulness confirm Davis' 1986 Technology Acceptance Model (Figure 2) where he also found them to be strong determinants of attitude towards the use of a technology. From Table 6 and Figure 9, the relationship between ease of use and usefulness was confirmed as a strong one as in Davis' initial model (Figure 2). Going further to the TAMZIM, usefulness is strongly influenced by enjoyment, availability of information and income. Enjoyment is particularly important to the younger generations and hence banks and supermarkets need to take advantage of this to encourage the use of online transaction platforms. The use of POS assumes that one has money in the bank or mobile phone which is dependent on the amount of income one earns. We also concluded that gender moderated the relationship between reliability, availability of information and computer literacy while age moderated the relationship between enjoyment and bank charges.

It is hoped that TAMZIM developed in this paper will fill the information and theory gap in research on online transactions in the retail industry in Zimbabwe. The researchers thus recommend customers to transact using online platforms, particularly in buying groceries from supermarkets in order to take advantage of the benefits of using them. Banks and supermarkets are urged to take heed of the identified factors with a strong positive relationship with perceived usefulness and perceived ease of use (without ignoring those with a moderate and weak relationship) in order to enhance the use of online transaction platforms by customers. Moreover, they are urged to develop marketing strategies that are gender biased and that target different age groups particularly with respect to relationships identified as strong (without ignoring moderate and weak relationships). Policy makers, particularly the government, are recommended to develop economic policies that enhance a productive economy which will increase cash flows to enable people to have money in their electronic wallets and hence encourage the use of online transaction platforms. Other stakeholders like Internet service providers are recommended to provide quality Internet connectivity in order to mitigate some of the Internet availability challenges. It is hoped that the results of this study will be used as a foundation for further studies. Further research can be undertaken to test TAMZIM in various environments in Zimbabwe, in the Diaspora and internationally in an effort to enhance adoption and use of online transaction platforms worldwide.

\section{Acknowledgements}

The authors express their gratitude to the National University of Science and Technology Research Board for providing funding for this study. 


\section{References}

Al-Ghaith, W., Sanzogni, L., \& Sandhur, K. (2010). Factors Influencing the Adoption and Usage of Online Services in Saudi Arabia. The Electronic Journal on Information Systems in Developing Countries, 40(1), 1-32. Retrieved from http://www.ejisdc.org

Ankit, S. (2011). Factors Influencing Online Banking Customer Satisfaction and Their Importance in Improving Overall Retention Levels: An Indian Banking Perspective. Information and Knowledge Management, 1(1), $45-54$. Retrieved from http://www.iiste.org/Journals/index.php/IKM/article/viewFile/690/583

Bailey, K. D. (1987). Methods of Social Research ( ${ }^{\text {rd }}$ ed.). London: Macmillan.

Baten, M. A., \& Kamil, A. (2010). E-Banking of Economical Prospects in Bangladesh. Journal of Internet Banking and Commerce. 15(2), 1-10. Retrieved from http://www.arraydev.com/commerce/jibc/

Bernardo, M. (2013). Point of Sale. Retrieved from http://www.slideshare.net/yuri56/point-of-sale-29179086

Boundless. (2015a). Types of Internet Advertising. Boundless Marketing. Retrieved from https://www.boundless.com/marketing/textbooks/boundless-marketing-textbook/social-media-marketing-15/introd uction-to-social-media-and-digital-marketing-98/types-of-Internet-advertising-483-10593/

Boundless. (2015b). The Many Goals of Persuasion: Boundless Marketing. Retrieved from https://www.boundless.com/marketing/textbooks/boundless-marketing-textbook/integrated-marketing-communicat ions-12/understanding-promotion-82/the-many-goals-of-persuasion-408-10598/

Cheng, V. M. Y. (2001). Enhancing Creativity of Elementary Science Teachers-a preliminary study. Asia-Pacific Forum on Science Learning and Teaching, 2(2), 1-23. Retrieved from https://www.ied.edu.hk/apfslt/download/v2_issue2_files/chengmy/chengmy.pdf

Chitungo, S. K., \& Munongo, S. (2013). Extending the Technology Acceptance Model to Mobile Banking Adoption in Rural Zimbabwe. Journal of Business Administration and Education, 3(1), 51-79. Retrieved from http://infinitypress.info/index.php/jbae/article/viewFile/100/90.

Chuttur, M. Y. (2009). Overview of the Technology Acceptance Model: Origins, Developments and Future Directions. Sprouts: Working Papers on Information Systems, 9(37), 1-23. Retrieved from http://sprouts.aisnet.org/9-37

Confederation of Zimbabwe Industries. (2014). 2014 CZI Manufacturing Sector Survey Report. Retrieved from http://www.czi.co.zw/images/Presentations/2014.pdf

Daniel, E. (1999). Provision of electronic banking in the UK and the Republic of Ireland. International Journal of Bank Marketing, 17(2), 72-82. Retrieved fromhttps://doi.org/10.1108/02652329910258934

Davis, F. D. (1986). A Technology Acceptance Model for empirically testing new-end user information Systems: Theory and Results. (Doctoral dissertation). Massachusetts Institute of Technology, Massachusetts, United States of America. Retrieved from http://hdl.handle.net/1721.1/15192

Davis, F. D., Baggozi R. P., \& Warshaw, P. R. (1989). User Acceptance of Computer Technology: A comparison of two theoretical Models. Management Science, 35(8), 982-1003. https://doi.org/10.1287/mnsc.35.8.982

Dolnicar, S., Grün, B., Leisch, F., \& Rossiter, J. (2011). Three good reasons NOT to use five and seven point items. Research Online: University of Wollongwong, Australia. Retrieved from http://ro.uow.edu.au/cgi/viewcontent.cgi?article=1821\&context=commpapers

Dube, C., \& Gumbo, V. (2017). Adoption and Use of Information Communication Technologies in Zimbabwean Supermarkets. Journal of Applied Economics and Finance, 4(1), 84-92. https://doi.org/10.11114/aef.v4i1.1860

Dube, T., Chitura, T., \& Runyowa, L. (2009). Adoption and use of Internet Banking in Zimbabwe: An exploratory Study. Journal of Internet Banking and Commerce, 14(1). Retrieved from http://www.arraydev.com/commerce/jibc/2009-04/Dube\%20etal.pdf

Explorable. (2009). Statistical Correlation: Strengths of relationships between variables. Retrieved from https://explorable.com/statistical-correlation

Fishbein, M., \& Ajzen, I. (1975). Belief, Attitude, Intention, and Behavior: An Introduction to Theory and Research. London: Addison-Wesley Publishing Company. Retrieved http://home.comcast.net/ icek.aizen/book/preface.pdf

George, D., \& Mallery, P. (2003). SPSS for Windows step by step: A simple guide and reference. (4th ed.). Boston: Allyn\& Bacon. Retrieved from http://wps.ablongman.com/wps/media/objects/385/394732/george4answers.pdf 
Gilbert, L., \& Hewitt, J. (2013). Online Transaction Processing. Retrieved from http://searchdatacenter.techtarget.com/definition/OLTP

Gono, G. (2012). Monetary Statement Policy, Reserve Bank of Zimbabwe. Retrieved from www.rbz.co.zw/.../2012\%20MPS/Mid\%20Term\%20MPS\%20July\%2020

Goyal, K. A., \& Joshi, V. (2011). A Study of Social and Ethical issues in Banking Industry. International Journal of Economics, 2(5), 49-57. Retrieved from http://www.ijeronline.com/documents/volumes/Vol\%202\%20issue\%205/ijer20110205SO\%285\%29.pdf

Gunesh, R. (2005). Statistical Correlation. Retrieved from http://pages.intnet.mu/cueboy/education/notes/statistics/pearsoncorrel.pdf.

Hadadi, N. A., Otaif, H. M., Faqihi, A. Y., \& Al-ahmadi, W. (2006). E-Banking - Benefits and Challenges.the Bachelor of Business Administration Degree dissertation. Jazan University, Jazan, Saudi Arabia. Retrieved from http://colleges.jazanu.edu.sa/GirlsCampus/bac/Documents/10.pdf.

Hall, B. H., \& Khan, B. (2002). Adoption of New Technology: New Economy Handbook. Retrieved from http://eml.berkeley.edu// bhhall/papers/HallKhan03\%20diffusion.pdf

Hossain, M., \& Bari R. (2006). Understanding of ATM (Automated Teller Machine) in Bangladesh. Bachelor of Computer Science and Engineering Dissertation BRAC University, Dhaka, Bangladesh. Retrieved from http://dspace.bracu.ac.bd/bitstream/handle/10361/479/Understanding+of+ATM+in+Bangladesh.pdf?sequence=1

Hussain, M. A. (2013). A Questionnaire Approach based on the Technology Acceptance Model for Mobile Tracking on Patient Progress Applications. Journal of Computer Science, 9(6), 763-770.

https://doi.org/10.3844/jcssp.2013.763.770

Jefferis, K., Chigumira, G., \& Chipumho, E. (2013). A Review of Zimbabwe's Optimum Future Currency Regime'. Zimbabwe Economic Policy Analysis and Research Unit. Retrieved from http://elibrary.acbfpact.org/acbf/collect/acbf/index/assoc/HASHc812.dir/doc.pdf

Jennings, J. (2013). Creative Problem Solving with SCAMPER. Retrieved from http://www.cedfa.org/downloads/Music/Creative\%20Problem\%20Solving\%20with\%20SCAMPER.pdf

Klopping, I. M., \& McKinney, E. (2004). Extending the Technology Acceptance Model and the Task-Technology Fit Model to Consumer E-Commerce. Information Technology, Learning, and Performance Journal, 22(1), 35-48. Retrieved from http://iris.nyit.edu/ kkhoo/Spring2008/Topics/TTF/ExtendTech_Performance.pdf

Kotler, P., \& Keller, K. L. (2006). Marketing Management (12 ${ }^{\text {th }}$ ed.). New Jersey: Prentice Hall.

Laerd Statistics. (2013). Pearson Product-Moment Correlation. Retrieved from https://statistics.laerd.com/statistical-guides/pearson-correlation-coefficient-statistical-guide.php

Learntech. (2015). Data Analysis: Pearson's Correlation Coefficient. Health and Applied Sciences: University of the West of England. Retrieved from http://learntech.uwe.ac.uk/da/Default.aspx?pageid=1442

Lee, M. (2009). Factors influencing the adoption of Internet banking: An integration of TAM and TPB with perceived risk and perceived benefit. Journal of Electronic Commerce Research and Applications.Res(Appl), 130-141. https://doi.org/10.1016/j.elerap.2008.11.006

Ma, Q., \& Liu, L. (2004). The Technology Acceptance Model: A Meta-Analysis of Empirical Findings. Journal of Organizational and End User Computing, 16(1), 59-72. https://doi.org/10.4018/joeuc.2004010104

Ma, Z. (2012). Assessing Serviceability and Reliability to Affect Customer Satisfaction of Internet Banking. Journal of Software, 7(7), 1601-1607. https://doi.org/10.1016/j.elerap.2008.11.006

McDowell, G. (2014). Types of Internet Access Technologies explained and what you should expect. Retrieved from http://www.makeuseof.com/tag/types-of-Internet-access-technologes-explained-and-what-you-should-expect/

Meerapur, A. (2014). Online Transaction Processing (OLTP). Retrieved from http://www.studymode.com/essays/Online-Transaction-Processing-Oltpthe-Following-Is-65509396.html

Mutengezanwa, M., Mauchi, F. N., Dube, T., \& Gombarume, F. (2014). Factors Influencing the Adoption and Usage of Internet Banking by Consumers in Zimbabwe. Journal of International Academic Research For Multidisciplinary, 2(7). Retrieved from

http://digilib.buse.ac.zw:8090/xmlui/bitstream/handle/11196/525/mutengezanwa.pdf?sequence=1

Myers, D. G. (2015). Social Psychology Glossary. McGraw Online Learning Centre. Retrieved from http://highered.mheducation.com/sites/0072413875/student_view0/glossary.html 
Nasri, W. (2011). Factors Influencing the Adoption of Internet Banking in Tunisia. International Journal of Business and Management, 6(8), 143-160. https://doi.org/10.5539/ijbm.v6n8p143

Padoa-Schioppa, T. (2003). A Glossary of terms used in payments and settlements systems. Retrieved from http://www.bis.org/cpmi/publ/d00b.pdf

Quesenbery, W. (2001). Looking Beyond 'Ease of Use'. Proceedings of the 48th Annual Conference. Society for Technical Communication (STC), United States of America: Chicago. Retrieved from www.wqusability.com/articles/more-than-ease-of-use.html

Rahmani, Z., Tahvildari, A., Honarmand, H., Yousefi, H., \& Daghighi, M. S. (2012). Mobile Banking and its Benefits. Arabian Journal of Business and Management Review,2(5), 37-40. https://doi.org/10.12816/0002266

Renny, S. E., Guritno, S., \& Siringoringo, H. (2013). Perceived Usefulness, Ease of use, and Attitude Towards Online Shopping Usefulness Towards Online Airlines Ticket Purchase. Procedia - Social and Behavioral Sciences, 81, 212-216. https://doi.org/10.1016/j.sbspro.2013.06.415

Roche, I. D. (2014). An Empirical Investigation of Internet Banking Service Quality, Corporate Image and the Impact on Customer Satisfaction; With Special Reference to Sri Lankan Banking Sector. Journal of Internet Banking and Commerce, 19(2). Retrieved from http://www.arraydev.com/commerce/JIBC/2014-08/Isuriv03.pdf

Rojean, T. G. (2014). Simple, affordable and safe: the French are taking to online banking. Retrieved from http://groupe.boursorama.fr/static-1404169261/cache/attachment/file/

Shambare, R. (2013). Technology readiness and EFTPoS usage in Zimbabwe. International Journal of Business and Economic Development, 1(1), 13-33. Retrieved from http://ijbed.org/admin/issue/pdf/volume_12345/2.pdf

Statpremier. (2006). The Correctional Co-efficient: San Jose State University. Retrieved from http://www.sjsu.edu/faculty/gerstman/StatPrimer/correlation.pdf

Steeneken, F., \& Ackley, D. (2012). A complete Model of the Supermarket Business. Retrieved from http://www.bptrends.com/publicationfiles/01-03-2012-ART-Supermarket\%20Article-steeneken-Ackley\%2011122 6.pdf

Steward, J. (1996). Managing Change Through Training and Development. London: Kogan Page Ltd.

Sura, J. (2011). Statistical Analysis: A Manual on Dissertation and Thesis Statistics in SPSS: Statistics Solutions. Retrieved from http://www.statisticssolutions.com/wp-content/uploads/SPSS\%20Manual.pdf

Takele, Y., \& Sira, Z. (2013). Analysis of Factors Influencing Customers' Intention to the Adoption of E-Banking Service Channels in Bahir Dar City: An Integration of TAM, TPB and PR. European Scientific Journal, 9(13), 402-417. Retrieved from http://eujournal.org/index.php/esj/article/view/1061/1095

Tan, P. J. B. (2013). Applying the UTAUT to Understand Factors Affecting the Use of English E-learning Websites in Taiwan'. Sage Open Access Articles. https://doi.org/10.1177/2158244013503837

Tavakol, M., \& Dennick, R. (2011). Making sense of Cronbach's alpha. International Journal of Medical Education, 2 , 3-55. https://doi.org/10.5116/ijme.4dfb.8dfd

Taylor, R. (1990). Interpretation of the Correlation Coefficient: A Basic Review. Journal of Diagnostic Medical Sonography, 6(1), 35-39. https://doi.org/10.1177/875647939000600106

Venkatesh, V. (2000). Determinants of perceived ease of use: Integrating perceived behavioral control, computer anxiety and enjoyment into the technology acceptance model. Information Systems Research, 11(4), 342-365. https://doi.org/10.1287/isre.11.4.342.11872

Venkatesh, V., \& Bala, H. (2008). Technology Acceptance Model 3 and a Research Agenda on InterventionsDecision Sciences, 39(2), 273-315. Retrieved from http://onlinelibrary.wiley.com/doi/10.1111/j.15405915.2008.00192.x/pdf

Venkatesh, V., \& Davis, F. D. (1996). A model of the Antecedents perceived Ease of Use: Development and Test. Decision Sciences, 27(3), 451-481. https://doi.org/10.1111/j.1540-5915.1996.tb01822.x

Venkatesh, V., \& Davis, F. D. (2000). Theoretical Extension of the Technology Acceptance Model: Four Longitudinal Field Studies. Management Science, 46(2), 186-204. https://doi.org/10.1287/mnsc.46.2.186.11926

Venkatesh, V., Morris, M. G., Davis, F. D., \& Davis, G. B. (2003). User Acceptance of Information Technology: Toward a Unified View. MIS Quarterly,27(3), 425-478. Retrieved from https://csdl-techreports.googlecode.com/svn/trunk/techreports/2005/05-06/doc/Venkatesh2003.pdf 
Vijayasarathy, L. R. (2004). Predicting consumer intentions to use on-line shopping: the case for an augmented technology acceptance model. Information and Management Journal, 14(6), 747-762. https://doi.org/10.1016/j.im.2003.08.011

Visualware. (2007). Never mind the connection speed, measure the consistency!: Visualware Incorporated.Retrieved fromhttp://www.myconnectionserver.com/resources/whitepapers/connection_quality.pdf

Zimswitch Technologies. (2013). Online Payments. Retrieved from http://www.zimswitch.co.zw/

\section{Appendix A}

Customer Questionnaire

Factors influencing the adoption and use of Online Transaction in the Retail Industry in Zimbabwe.

\section{Preamble}

The aim of this study is to determine the factors influencing the adoption and use of online transaction platforms in the retail industry in Zimbabwe. The researchers would appreciate it if you could assist by completing the questionnaire as a customer for banks and supermarkets. All responses will be kept strictly confidential.Individual names and personal details will not be mentioned in the report.

\section{Instructions}

- Respond to all questions and to the best of your knowledge and experiences.

- There are no right or wrong answers.

- Online transaction platforms in this questionnaire refer to Internet banking, Automated Teller Machines (ATMs), Mobile banking and Point of Sale (POS) as you use them in your banks and supermarkets in Zimbabwe.

Please tick in the appropriate box representing your answer in the questions below.

1. What is your Gender?

Male $\square$ (1) $\square$ Female

2. What is your age group?
30 and below
(1)
$31-40$
(2)
$41-50$

$$
51-60
$$
61 and above
(5)

3. What is your highest educational qualification?
'O' Level and below
'A' Level
(2)
Diploma
$1^{\text {st }}$ Degree
(4) Masters Degree
(5)

$$
\text { Other, } \square \quad \text { specify }
$$
$\mathrm{PhD}$
(6)

4. Where do you work?
Private Sector Employed

(3) Student

Retired

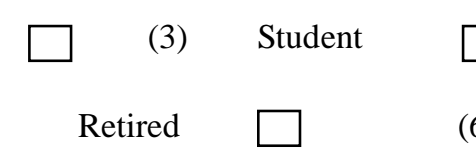

Public Sector Employed

(4) Unemployed

For each factor listed in question 5, please rate the extent of the factor's influence on online transactions by putting a tick in the appropriate option (Great Extent, Little Extent or Not Sure). 
5. To what extent do you think the following factors influence the adoption and use of online transactions as a whole?

\begin{tabular}{|c|c|c|c|c|}
\hline \multirow[t]{2}{*}{ No. } & \multirow{2}{*}{$\begin{array}{l}\text { Factor influencing adoption and use of } \\
\text { Online Transaction }\end{array}$} & \multicolumn{3}{|c|}{ Extent of Influence } \\
\hline & & $\begin{array}{c}\text { Great Extent } \\
\text { (1) }\end{array}$ & $\begin{array}{c}\text { Little Extent } \\
\text { (2) }\end{array}$ & $\begin{array}{c}\text { Not Sure } \\
\text { (3) }\end{array}$ \\
\hline 1. & Ease of use & & & \\
\hline 2. & Usefulness & & & \\
\hline 3. & Enjoyment & & & \\
\hline 4. & Quality of Connectivity & & & \\
\hline 5. & Accessibility & & & \\
\hline 6. & Reliability & & & \\
\hline 7. & Bank Charges & & & \\
\hline 8. & Security and Privacy & & & \\
\hline 9. & Availability of Information & & & \\
\hline 10. & Computer Literacy & & & \\
\hline 11. & Availability of Internet & & & \\
\hline
\end{tabular}

Thank you for completing this questionnaire.

Cinderella Dube

\section{Appendix B}

Bank Questionnaire

Factors influencing the adoption and use of Online Transactions in the Retail Industry in Zimbabwe.

\section{Preamble}

The aim of the study is to determine the factors influencing the adoption and use of online transaction platforms in the retail industry in Zimbabwe. The researchers would appreciate it if you could assist by completing the questionnaire as part of management of your organisation. All responses will be kept strictly confidential. Individual names, personal details or the name of your organisationwill not be mentioned in the report.

\section{Instructions}

- $\quad$ Respond to all questions and to the best of your knowledge and experiences. There are no right or wrong answers.

- Online transaction platforms in this questionnaire refer to Internet banking, Automated Teller Machines (ATMs), Mobile Banking and Point of Sale (POS) as they are used in your bank, with particular reference to buying groceries in supermarkets in Zimbabwe.

Please tick in the appropriate box representing your answer in question 1.

1. What is your position in the organisation?

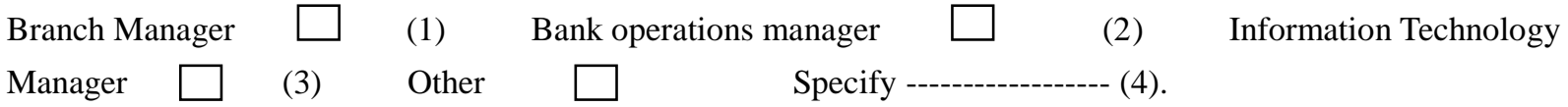

For each factor listed in question 2, please rate the extent of the factor's influence on online transactions by putting a tick in the appropriate option (Great Extent, Little Extent or Not Sure). 
2. To what extent do you think the following factors influence the adoption and use of online transactions in your bank?

\begin{tabular}{|c|c|c|c|c|}
\hline \multirow[t]{2}{*}{ No. } & \multirow{2}{*}{$\begin{array}{l}\text { Factor influencing adoption and use of Online } \\
\text { Transaction }\end{array}$} & \multicolumn{3}{|c|}{ Extent of Influence } \\
\hline & & $\begin{array}{l}\text { Great Extent } \\
\text { (1) }\end{array}$ & $\begin{array}{l}\text { Little Extent } \\
\text { (2) }\end{array}$ & $\begin{array}{l}\text { Not Sure } \\
\text { (3) }\end{array}$ \\
\hline 1. & Ease of use & & & \\
\hline 2. & Online Service & & & \\
\hline 3. & Quality of Connectivity & & & \\
\hline 4. & Bank charges & & & \\
\hline 5. & Usefulness & & & \\
\hline 6. & Enjoyment & & & \\
\hline 7. & Accessibility & & & \\
\hline 8. & Reliability & & & \\
\hline 9. & Availability of Internet & & & \\
\hline 10. & Security and Privacy & & & \\
\hline 11. & Advertising & & & \\
\hline 12. & Management attitude & & & \\
\hline 13. & Computer literacy & & & \\
\hline 14. & Income one earns & & & \\
\hline
\end{tabular}

Thank you for completing this questionnaire.

Cinderella Dube

Appendix C

Supermarket Questionnaire

Factors influencing the adoption and use of Online Transactions in the Retail Industry in Zimbabwe.

\section{Preamble}

The aim of this study is to determine the factors influencing the adoption and use of online transactions platforms in the retail industry in Zimbabwe. The researchers would appreciate it if you could assist by completing the questionnaire as part of management of your organisation. All responses will be kept strictly confidential. Individual names, personal details or the name of your organisationwill not be mentioned in the report.

\section{Instructions}

- Respond to all questions and to the best of your knowledge and experiences. There are no right or wrong answers.

- Online transaction platforms in this questionnaire refer to Internet banking, Automated Teller Machines (ATMs), Mobile Banking and Point of Sale (POS) as they are used by customers in buying groceries in your supermarkets in Zimbabwe.

Please tick in the appropriate box representing your answer in question 1.

1. What is your position in the organisation?

Branch Manager

Till-operator Supervisor
Assistant Manager
(3) Other $\square$ Specify,

(2)

2. To what extent do you think the following factors influence the adoption and use of online transactions in your Supermarket? 
For each factor listed in question 2, please rate the extent of the factor's influence on online transactions by putting a tick in the appropriate option (Great Extent, Little Extent or Not Sure).

\begin{tabular}{|c|c|c|c|c|}
\hline \multirow[t]{2}{*}{ No. } & \multirow{2}{*}{$\begin{array}{l}\text { Factor influencing adoption and use of } \\
\text { Online Transactions }\end{array}$} & \multicolumn{3}{|c|}{ Extent of Influence } \\
\hline & & $\begin{array}{c}\text { Great Extent } \\
\text { (1) }\end{array}$ & $\begin{array}{l}\text { Little Extent } \\
\text { (2) }\end{array}$ & $\begin{array}{c}\text { Not Sure } \\
\text { (3) }\end{array}$ \\
\hline 1. & Ease of use & & & \\
\hline 2. & Online Service & & & \\
\hline 3. & Quality of Connectivity & & & \\
\hline 4. & Bank charges & & & \\
\hline 5. & Usefulness & & & \\
\hline 6. & Enjoyment & & & \\
\hline 7. & Accessibility & & & \\
\hline 8. & Reliability & & & \\
\hline 9. & Availability of Internet & & & \\
\hline 10. & Security and Privacy & & & \\
\hline 11. & Advertising & & & \\
\hline 12. & Management Attitude & & & \\
\hline 13 & Computer Literacy & & & \\
\hline 14. & Income & & & \\
\hline
\end{tabular}

Thank you for completing this questionnaire.

Cinderella Dube

\section{Copyrights}

Copyright for this article is retained by the author(s), with first publication rights granted to the journal.

This is an open-access article distributed under the terms and conditions of the Creative Commons Attribution license which permits unrestricted use, distribution, and reproduction in any medium, provided the original work is properly cited. 